\title{
Intercultural Management between Tunisia and Europe
}

\author{
Hanen Khanchel ${ }^{1} \&$ Karim Ben Kahla ${ }^{2}$ \\ ${ }^{1}$ Institute of Advanced Business Studies, Carthage, Tunisia \\ ${ }^{2}$ High Business School, Campus of Manouba, 2010, Manouba, Tunisia \\ Correspondence : Karim Ben Kahla, High Business School, Campus of Manouba, 2010, Manouba, Tunisia. E-mail: \\ Karim.Benkahla@gmail.com
}

Received: September 21, 2018

Accepted: October 21, 2018

Online Published: October 23, 2018

doi:10.5430/jbar.v7n2p40

URL: https://doi.org/10.5430/jbar.v7n2p40

\begin{abstract}
The subject of this paper is to report on the problem of cultural differences in management between Tunisia and Europe in the context of the company.

Thus, the paradox between values and the way of managers' life in companies. Therefore, daily strategies also represent one's willingness to be accepted by society and not to be cut off.

The present article has three parts. The first is to identify the cultural foundations of European society, the Anglo-Saxons and the francophone's culture. The second is to show how Tunisian cultural values are unsuited to the European model. The third part is to propose some recommendations for adapting the strategies of Tunisian companies to their European partners. Based on the Tunisian cultural configuration and the information collected through the case studies, we recommend a code of conduct companies attempt to bring together all staff around common values and to foster a common culture where social responsibility can play an important role. These codes cannot be imposed but must correspond to the reality of the business under. It is difficult for a gap to be created between the speeches and the reality, leading to the de-involvement of managers.
\end{abstract}

Keywords: manager, culture, company, gender, europe, tunisia

\section{Introduction}

Today, with the economic and sociological changes that have affected Tunisian society, the representations conveyed by managers have changed (Ayari and Gobe, 2004). There is now a split between the public and private sectors. The first is a guarantee of an average but stable salary, the second offers managers a much higher income but at the cost of chronic instability (Ayari and Gobe, 2004). In 2011, managers accounted for $14.7 \%$ of employees in Tunisia (CRES, 2012). The rise in the rate of managers can be explained by the shift of activities towards the tertiary sector and the development of trades related to new technologies, research and development (Bouffartigue and Gadéa, 2000).

Regarding the feminization of managers, it is differentiated (Bouffartigue and Gadéa, 2000). In fact, inequalities persist in terms of access to power and decision-making functions (Laufer and Fouquet, 2001). Women are often confronted with a "glass ceiling" and have less access to hierarchical positions (Ben Hassine, 2007). They are often limited to administrative or relational activities (Gadéa, 2003). Thus, in the private sector, out of 30 large Tunisian companies, only 4 of them have a woman in their works council (GIZ, 2013). In the public sector, $15.2 \%$ of management positions are held by women (Ben Hassine, 2007). Bourdieu (1998) gives an explanation for this phenomenon by the fact that women are irrevocably confined to positions less prestigious than men by the universal principle of male domination. For him, "the formal equality between men and women tends to conceal that, all other things being equal, women still occupy less favored positions".

Another element strongly characterizes the Tunisian context. This is the rise in unemployment of graduates aggravated by the social and political events that occurred following the revolution of January 14, 2011. Since 2006, there has been a rise in the unemployment rate of higher education graduates, which reached $31.4 \%$ in 2014 (INS, 2014). This can be explained, among other things, by the structural and functional constraints on the Tunisian labor market due in particular to the weak capacity of the national economy to create jobs to reverse the upward trend in unemployment (National Observatory of Labor). 
The subject of this paper is to study the problem of cultural differences in management between Tunisia and Europe in the context of the company.

The present article has three parts. The first is to identify the cultural foundations of European society, the Anglo-Saxons and the francophone's culture. The second is to show how Tunisian cultural values are unsuited to the European model. The third part is to propose some recommendations for adapting the strategies of Tunisian companies to their European partners.

A first problem appears in the distinction between managers and non-managers. In Tunisia, the difference between managers and non-managers is very marked for fairly well-established socio-historical reasons. Research has shown that the border between managers and non-managers is mainly justified by the size and nature of the network of relationships maintained. This could explain why women, less involved in many networks of relationships, would have less access to positions of power in Tunisian companies. Talking about cultural differences in management requires knowledge of the profiles and roles of the executive category which naturally includes the smaller population of leaders. Reality forces us to say that this knowledge is still limited. Thus, the paradox between their values and the way of manager's life in society imposes on them. Therefore, daily strategies also represent one's willingness to be accepted by society and not to be cut off.

The question asked: how cultural dimension is managed in Tunisia differently than in Europe?

\section{Methodology}

In this qualitative research, we conducted a study of five cases of public and private companies allowing us to apprehend and analyze a rarely studied situation in management sciences (Yin, 2003). The purpose of the case study is descriptive in the sense that it focuses on "describing an intervention and the actual context in which it occurred" (Yin, 2003: 15). The case we are looking at has been selected for a theoretical enrichment of the concept of coordination in volatile environment. It is in fact to construct a theoretical sample, considering the elements of theory developed previously like criteria of selection of the case (Yin, 2003). Analytical generalization is then facilitated (Ayerbe and Missonier, 2007).

\section{The Main Foundations of Culture}

By observing the communication and interaction between people belonging to different cultural systems, Hall (1990) distinguishes three main foundations that constitute so many keys to understanding and deciphering the behavior of the foreigner: time, space and context Communication.

Time is perceived and organized differently from one culture to another. This is of course punctuality and accuracy, appreciated by some, less important or more flexible in other cultures. We can ask ourselves from how many minutes we are "late", from how much delay we have to apologize, how long we will wait for someone, but it is also about the relative importance past, present and future. Trompenaars (1994) draws three circles for these three times, with a size and overlap as we perceive them: he thus visualizes the differences between the countries.

An extremely interesting aspect highlighted by Hall is the distinction between monochronic cultures and polychronic cultures. The monochronic time is linear, while the polychronic time is characterized by the simultaneity of different activities. We can say that the countries of northern Europe are rather monochronic, and the southern countries more polychronic. It must be emphasized, however, that in cultural differences, one is never in a dichotomous situation, but rather in a continuous line, on which one is sometimes more than one side, sometimes more than the other. For this reason, the table showing the differences between the two time systems should be used carefully (from Hall, 1990): 


\begin{tabular}{|ll|ll|}
\hline Polychronic system & Monochronic system \\
\hline$-\quad$ Concurrent tasks & - & One thing at a time. \\
$-\quad$ & - & We are dedicated exclusively to a task. \\
precedence & Interruptions and changes allowed. & Execution of the prime task
\end{tabular}

Space refers to attachment to the territory, strongly conditioned by culture. In addition to this territoriality, the space or personal bubble in which one lives is an important cultural element. Access in this personal bubble is forbidden, except to the most intimate, or so restricted and limited in time (in an elevator). The distance or proximity to which one can comfortably chat with another person varies considerably from one culture to another. Here again, the differentiation is between the cultures of Northern Europe (including Anglo-Saxon cultures) and those of the South. Indeed, a Frenchman discussing with an American will tend to approach to a comfortable distance for him, but uncomfortable for the American who, feeling threatened, will retreat until he is back to the wall and slips away apologetically. In the same vein, physical contact, such as hugging to say hello or touch to accentuate a point, will be more or less normal or frequent depending on the culture. Once again, all this is quite relative, since we will find cultures, Tunis for example, where the personal bubble is smaller than in European culture.

More cultures are implicit than explicit cultures, and that this aspect is one of the main and greatest difficulties in intercultural communication. Indeed, in collectivist cultures, which are also implicit, we avoid being direct to protect the face and to protect the face of the other. So we will avoid saying "no" because it makes the other face lose, but we will find multiple ways to say, or rather to say "no" without saying it: "I will do my best" n ' is not to be taken literally as an explicit person would, but to interpret as "it is impossible". This way of speaking is often perceived as confusing and even dishonest, but is actually for the one who speaks a mark of politeness and respect. If in Europe one asks: "You do not have his telephone number? The person arrested, who did not answer, "No, I do not have it". 


\begin{tabular}{|l|l|}
\hline Tunisian value system & European value system \\
\hline - Deductive reasoning. & - Inductive reasoning \\
- Polychronic organization. & - Monochronic organization \\
- Implicit communication relative importance of & - Explicit communication \\
unspoken and nonverbal language. & importance of verbal language \\
- Importance of the emotional relationship in the work. & conciseness in messages \\
- Orientation "to be"quality of life use & - Separation work, relations \\
-Islamic religion & - "Do" orientation work hard to succeed \\
- High formalism protocols, rites, labels & - Protestant religion \\
separation "you / you" & - Weak formalism appreciated simplicity \\
-Resistance to change & No separation "you / you" (eg "you") \\
high prioritization & - Low resistance to change \\
- Pyramid structure authoritarian & reformer \\
many hierarchical levels & Social Democracy \\
-Low social mobility & - Low ranking \\
importance of the role of elites & rake structure \\
public education system & participatory \\
- Low unionization & -Lower number of levels \\
ideological & high social mobility few elites \\
not integrated into the life of the company & democratic education system \\
- Decision flow order. & - Strong unionization pragmatic \\
- Size of companies. & integrated into the life of the company \\
dominant small and medium & -Debate \\
-Economic development. & -Large companies. \\
\hline
\end{tabular}

\section{Work, an Important Value for the Tunisian Manager?}

According to the cases studied, and in response to the question: "For each of the following things, say if in your life this is very important, somewhat important, not important or not important to all? 87\% of Tunisian managers said they considered work "very important" in their lives, ranking fourth among the most professional countries among the 59 countries surveyed by the World Values Survey (2010-2014). They are far ahead of their Egyptian neighbors in particular (with 61\%). This puts work in third place in the order of importance of Tunisians, after family and religion, and well after friends, hobbies, or politics.

Regarding the importance given to the family, it is very similar from one country to another (more than $90 \%$ of respondents say that the family is very important in their lives). Tunisians, from this point of view, do not depart from the rule (with a rate of $98 \%$ ). In other words, family, religion and work are considered to be the most important activities for Tunisians.

Admittedly, the Tunisian manager gives more importance to the work than the Egyptian, the European or the American but this rate is not the same according to the category of occupation. In fact, the survey reveals a certain divergence in the importance given to work by workers and other categories of occupation. Unemployment and precariousness thus appear to be decisive in the value given to work whatever the country of origin. The value given to the work being higher among employees (employees or self-employed), work thus representing one of the essential components of their identity and a vehicle for personal fulfillment and accomplishment (Garner and Méda, 2006). But this is significantly less relevant for the unemployed and pensioners for whom the value given to work declines significantly regardless of the country of origin. 


\section{Religion, an Important Value for the Tunisian Manager?}

In addition, particular importance is given to religion in Muslim countries compared to European and Anglo-Saxon countries. Indeed, we note a very large gap between the value given to religion in Muslim countries such as Tunisia and Egypt (around 94\%) and the European and Anglo-Saxon countries (not exceeding 40\%). On the other hand, in these countries there is a special attention to social and friendly relations (more than 50\%). The importance given to work in relation to leisure perceived in Tunisia is also noted in Egypte et en Espagne. Mais ce result is not universal. In Anglo-Saxon and Nordic countries such as Sweden, Great Britain and the United States, leisure and free time are considered more important than professional life.

\section{Importance Given to Each Activity According to Gender}

The cases studied reveals interesting differences between Tunisian women and men. It shows differences between men and women in terms of importance given to work, friends and hobbies, but they remain equal in the value given to the family. Thus we can conclude from this case studied that the Tunisian attributes a crucial importance to family values, quality of life and warm human relationships as confirmed by Lassoued (2008). At the same time, he values work (Séror and Rejeb 2006). For Ben Fadhel (1992) this reflects a balance between male values and feminine values according to Hofstede's (1991) cultural analyzes.

\section{Discussion}

The strategic choices for business development of companies depends on the size of the company, its specialization and its economic situation, only companies that cultivate a conception of the collective based on non-market values reconcile our sample, opportunities and collective supports. Of the five cases studied, only three under this scenario. Membership in a collective and adherence to common values occupy a central place in the strategy developed by these companies. But the values on which the collective is based are contrasted. Thus, the three public companies studied develop a sense of collective based on family and religion, while two private companies promote a sense of collective based on loyalty and recognition, maintained by participative cultural management strategies. The instillation of a sense of belonging and the constitution of the collective therefore operate on different bases.

Indeed, the strategies developed by the studied cases play a decisive role in the constitution of a collective that management wants to place under the sign of a common attachment to the family, to religion. A corporate culture that refers to tradition and continuity. Wedding contract, a guarantee of long-term commitment, loyalty, good morals and respect for tradition, is particularly appreciated. At the time of recruitment, the selection focuses on lifestyles and opinions as well as professional skills.

In fact, Tunisian managers seek, in the context of the company, a more emotional contact, similar to that maintained by members of the same family. Their globalizing way of belonging also leads them to be hampered by the compartmentalization they perceive through the operation of certain departments within their company. Operating themselves in a more open and cooperative relationship, each one has "his" responsibility, however, assistance is still in place depending on emergencies, even if some tasks do not directly meet their skills. They expect, often from their superiors, a more paternalistic than functional framework and can be disconcerted by excessive delegation of responsibilities. Finally, their diffuse way of belonging leads those not to understand that their evaluation is carried out solely on the criteria of economic performance, relational and human criteria often prevail over the functional criteria. Conversely, the European managers we met sometimes have a tendency to make hasty judgments on the competence of Tunisian managers by assimilating the importance they give to the criteria related to relational and family factors in the company to a lack of rigor or professionalism; similarly, they are surprised by what they interpret as a lack of clarity in the constituency of each other's roles. When they neglect the quality of the personal relationship, they have much harder time collecting relevant information and not getting the necessary commitment from their teams.

In our case studies, we noted some misunderstandings between the European and Tunisian management regarding the signs of power in the company. The former valued more the importance of diplomas and responsibility in management, and were surprised and shocked by the benefits in kind required by the Tunisian management.

These signs of recognition are important, because they concern not only comfort needs, but also recognition needs in the context of the company. Also, the management of the human resources, if it is exerted by the foreign management, must take into account these needs of recognition in order to limit the discomforts. In fact, the positioning of managers in relation to their organizational environment. The formal structure of the Tunisian company is often coupled with a relational organization. The identification of informally influential people and the relational networks that support them is not always easy for European expatriates who rely mainly on a formal 
structure. Their efforts are longer, and the paths they follow, to obtain for example information, cost them much more time and energy for less results than Tunisian managers. In this sense, their transaction costs are increased. The informal nature of the Tunisian structure destabilizes them, giving them the impression that they cannot control information. In addition, when the relationship of trust between Europeans and Tunisians is not well established, they may be tempted to adopt opportunistic behavior by playing on the vagueness of the information network, thus increasing the transaction costs of their partners' foreigners.

In the cases studied, the functioning of the community is based on the group and on the presence of a representative of the will of all, respected and it is the paternalistic style of the Tunisian management. We have seen in particular in our last study that Europeans clearly reject this model, which they consider unprofessional. However this attitude can also make them miss opportunities in their efficiency in managing teams and further increase their transaction costs.

Besides, the communication of information is essential. However, the difficulty the European have in interpreting the implicit context of Tunisian communication increases the cost of finding relevant information, leads them to stop facing their Tunisian counterparts and finally to become demotivated. This results in higher transaction costs. In addition, if trust is not established between partners, Tunisian managers can even play on the opacity of their communication, to increase their bargaining power against the European.

Management methods, mainly from the Europe, imposed a certain perception of time. Productivity, which in this context is the primary objective of any company, is indeed directly correlated to time, since it is defined by the ratio between the results obtained and the time devoted to them. Planning is also found in all aspects of business management.

Tunisian managers, in the context of the company, have certainly learned to use time, but their polychrome culture persists. Indeed, the biggest management difficulties spontaneously mentioned by European managers in the Tunisian context are related to the respect of schedules, deadlines and planning in general. For their part, Tunisian managers consider that the European lack flexibility and responsiveness in real time. We noted during our cases studied that in a negotiation, Tunisian managers also knew how to play on their polychrome dimension, by imposing on their European partners drifts of deadlines, in the name of their culture (Boudabbous, S, 2005).

\section{Conclusion}

The few elements reported from the cases studied above make it possible to understand the obstacles facing a Tunisian company when it operates in a European country. Tunisia's transition period since 2011 has been, from this point of view, a remarkable testing laboratory on both sides. The influence of the national culture on the management of companies and the life of the business is an unavoidable reality. Strategies developed in the early years of 2011 have been gradually abandoned in favor of framework more adapted to the local context. The Tunisian culture is a source of blockage on the path of development and value creation and the revolution of January 14, 2011 does not question this failure because business relations go beyond this framework. Cultural differences remain marked and manifest at the levels of national culture, corporate culture, and the personal culture of managers. When developing international cooperation in a foreign country, companies must evaluate the cultural context of their action. For companies, mastering cultural differences becomes a new competitive advantage.

In the end, we recommend a code of conduct, companies attempt to bring together all staff around common values and to foster a common culture where social responsibility can play an important role. These codes cannot be imposed but must correspond to the reality of the business under. It is difficult for a gap to be created between the speeches and the reality, leading to the de-involvement of managers.

\section{References}

Ayerbe, S. et Missonier, A. (2007). Validité interne et validité externe de l'étude de cas : principes et mise en œuvre pour un renforcement mutuel.

Ayari, M-B, Gobe, E., Les cadres supérieurs de la fonction publique tunisienne : réalités d'une condition socioprofessionnelle, Les cahiers du GDR Cadres, $N^{\circ} 8$, p.87-100.

Ben Fadhel A. (1992). Dynamique séquentielle : culture-Gestion. Fondements théoriques et analyse empirique du cas tunisien, Thèse d'Etat en Sciences de Gestion, Université de Nice.

Ben Hassine, A. (2007). Parcours de femmes cadres dans l'administration publique tunisienne: des femmes (pas) comme les autres, Télescope, Vol. $13 n^{\circ} 4$, p.42-53

Bennett, John, M-T. Claes, J. Forsberg, N. Flynn, W. Obenaus, T. Smith. (1998). Doing effective presentations in an intercultural setting. Vienne, Ueberreuter. 
Binon, Jean et Marie-Thérèse Claes. (1995). Intercultural communication and negotiation in a business environment. In : Jensen, A.A, K. Jaeger \& A. Lorentsen (eds). Intercultural competence. A new challenge for language teachers and trainers in Europe. Vol. II : The adult learner. Aalborg University.

Bollinger, D. et G. Hofstede. (1987). Les différence culturelles dans le management. Comment chaque pays gère-t-il ses hommes? Paris, Les Editions d'Organisation.

Bonnal, Françoise. 1990. Les goûts publicitaires des européens. In D. Schnapper et H. Mendras. Six manières d'être européen. Paris, Gallimard, Bibliothèque des Sciences Humaines.

Boudabbous, S. (2005). Approche culturelle des rapports entre Tunisiens et Occidentaux dans le cadre des activités d'une entreprise en Joint Venture, La Revue des Sciences de Gestion 2005/3 (n²13).

Bouffartigue, P., Gadéa, C. (2000). Sociologie des cadres, Repère La découverte, Paris.

Bourdieu, P. (1998). La domination masculine. Le seuil.

Centre de recherches et d'études sociales. (2012). Enquête sur la structure des salaires, Tunisie 2011, en collaboration avec le Bureau International de Travail, 58 pages

Gadéa, C. (2003). Les cadres en France. Une énigme sociologique, Belin, Paris.

Galisson, Robert. (1989). Lexique, langue et culture. Paris, CLE International, Collection D.L.E.

Gauthey, Franck et Dominique Xardel. (1990). Le management interculturel. Paris, Presses Universitaires de France. Collection Que sais-je ?

Garner, H., Méda, D. (2006). La place du travail dans l'identité des personnes », Données sociales - La société française, Edition 2006, p.623-630

GIZ. (2013). Plaidoyer pour une approche managériale adaptée : l'économie tunisienne et la diversité des genres, Tunis.

Hall, Edward T. et M. Hall. (1990). Understanding cultural differences. Germans, French and Americans. Maine, Interultural Press.

Hofstede, Geert. (1991). Cultures and organisations. Software of the mind. Londres, McGraw-Hill.

Institut National de la Statistique, Site officiel : www. INS. nat.tn

Lambert, Wallace.E. (1972). Developmental aspects of second language acquisition. In Lambert W.E. Language, psychology, and culture. Essays. Selected and introduced by Anwar S. Stanford CA, Stanford University Press, 9-31.

Laufer, J., Fouquet, A. (2001). À l'épreuve de la féminisation. In P. Bouffartigue (Éd.), Cadres, la grande rupture (pp. 249-267). Paris : La Découverte

Lassoued, K. (2008). l'adaptation culturelle $d u$ contrôle de gestion, Cas de la Tunisie, La comptabilité, le contrôle et l'audit entre changement et stabilité, HAL, France

Séror A., Rejeb S. (1996). Etude de cas de transfert des nouvelles technologies: l'Institut régional des sciences informatiques et des télécommunications de Tunis, Publication de l'Université de Laval.

Trompenaars, Fons. (1993). Riding the waves of culture. Londres, N. Brealey.

Trompenaars, Fons. (1994). L'entreprise multculturelle. Paris, Laurent Du Mesnil, Collection institut du management d'EDF et de GDF.

Usunier, Jean-Claude. (1990). Management international. Paris, Presses Universitaires de France.

Yin, R.K. (2003). Case Study Research: Design and Methods. Sage. Thousand Oaks, California.

World Values Survey. (2014). Site officiel: www.worldvaluessurvey.org 